Check for updates

Newcastle upon Tyne, UK

stokel@gmail.com

Cite this as: BMJ 2021;374:n2053

http://dx.doi.org/10.1136/bmj.n2053

Published: 24 August 2021
COVID-19

\section{Covid-19: Which countries are doing well on test and trace-and how can we tell?}

\author{
With the UK's test and trace scheme much maligned, Chris Stokel-Walker asks which countries \\ have done better, and how we can measure "success"?
}

\section{Chris Stokel-Walker freelance journalist}

Research by Imperial College London suggests effective test, trace, and isolate systems could reduce the reproductive rate of SARS-CoV-2 by $26 \% .{ }^{1}$ Yet different countries have had wildly different levels of success with their systems.

Measuring "success," however, is hard. Systematic reviews of test and trace systems worldwide often struggle to provide a definitive answer. ${ }^{2}$ "It all depends on the outcome measure," says Jay Patel, a researcher at the University of Edinburgh's Global Health Governance Programme.

Different countries have different goals for their pandemic strategy. Some, such as New Zealand, have pursued as close to a zero covid strategy as possible, while in the UK the test and trace system has been used to try to keep cases at a level that is manageable for the NHS. Slovakia decided to test its entire population of 5.5 million people ${ }^{3}$ and to require those who tested positive to download an app that prompts you at any time of the day to show your face to prove that you are isolating.

Different types of testing have also been deployed: in Austria, anyone is able to claim free polymerase chain reaction (PCR) tests, considered the gold standard, under their mandatory health insurance, while the UK instead makes faster but less sensitive lateral flow tests available free, PCR tests being available only to those who have symptoms.

\section{Measure for measure}

One measure used to calculate the success of a testing regime is whether they meet an informal benchmark set by Michael Ryan, executive director of the World Health Organization's health emergencies programme, more than a year ago. In March 2020, Ryan said countries should be conducting between 10 and 30 tests for every positive case they find. ${ }^{4}$

By that measure, countries such as Italy, Japan, and Spain would flunk the test. ${ }^{5}$ Countries considered to be doing well when it comes to testing, such as New Zealand (1543 tests per positive case as of 9 August), Taiwan (1481), Australia (637), and Singapore (534) lead the way.

Austria, held up as a paradigm of good infection management, is also near the top of the rankings, with 662 tests per positive case. It also ranks highly when measuring tests conducted per 1000 people (7693 tests per 1000). Yet using this measure, the UK-widely considered to have done badly on testing and tracing ${ }^{6}$-is among the world leaders with 3334 tests per 1000 people.

This leaves experts reluctant to declare successes and failures. "All countries are doing well and doing poorly,” says Maria van Kerkhove, covid-19 technical lead at WHO. "Your ability to test is based on capacity, access to equipment, and people who can carry out those tests."

The affordability of PCR testing has an impact on the ability of a country to develop and deploy an effective test and trace programme. "It's not just a matter of will," says van Kerkhove. "It's a matter of making sure there's a way."

For Sebastien Cognat, who works in WHO's health emergencies programme, it's not simply a case of numbers and who is conducting the most tests. "It's making sure that it's done at the right time in the right way," he says. Countries that test well, in his opinion, are those that have a good strategy according to the resources they have and adapt to supply and demand blips in real time.

James Wood, associate professor at the University of New South Wales, Australia, says there are three components of a successful test, track, and trace system. "One is being fast, and that requires identifying contacts quickly and getting tests done quickly," he says. The second is complete coverage, finding all those with symptoms and their contacts. The third key element is good adherence to isolation requests.

Wood says the scale of testing-in terms of tests per head of population-isn't as important as testing the right people, not least with the new delta variant of SARS-CoV-2, the increased transmissibility of which makes it important to bear down quickly and accurately on those affected and their contacts before case numbers rise out of control. Such "cluster busting" targeted testing has been used in countries where capacity is limited, such as Japan and South Korea, with comparative success when compared with the UK's more scattergun approach. ${ }^{7}$

\section{Learnt lessons}

Many Asian countries have done better than Europe and the Americas in managing the pandemic in terms of total cases and deaths. This has broadly been attributed to better preparation following the scars of previous epidemics, including SARS and MERS. The hard restrictions imposed have undoubtedly 
reduced movement and therefore viral spread, but whether test and tracing of contacts has contributed is more questionable.

Certainly, countries that had pre-existing testing systems for respiratory diseases have managed to act on covid-19 testing quicker, says Celine Barnadas, technical officer at WHO. Some countries with strong pre-existing testing for tuberculosis, in Africa, for instance, have managed to repurpose their laboratories for SARS-CoV-2, ${ }^{8}$ she says.

Patel points to Senegal. "In February 2020, the testing system for SARS-CoV-2 was great," he says. "Results were returned routinely within 24 hours-in many cases, quicker-and the Institute Pasteur de Dakar was one of only two labs in Africa at the time able to test for coronavirus." Senegal spent time early on in the pandemic training staff from dozens of other countries in Africa to help test for and diagnose covid-19. "It can have a big impact regionally," says Patel.

Yet countries like Sierra Leone found themselves on the one hand well prepared in terms of a tracing system because of the 2014 Ebola epidemic, but on the other hand faced problems with laboratory and diagnostic testing capacity. "They didn't have the advanced tools, basically," says Patel. They weren't able to scale up their infrastructure and they struggled.

The way the systems are set up also plays a large role in their effectiveness. West African test and trace systems have been deployed in an entirely different way to those in the UK and US, for instance. "The emphasis on community health workers in West Africa was seen as the vehicle by which to deliver the system," says Patel.

Western, urbanised countries took a different path, centralising the effort to reach everyone. At times, the UK has strayed from its centralised strategy, allowing local councils to go door-to-door in covid-19 hotspots to try and keep a lid on spiralling infection rates. But, by and large, the centralised system remained the key method-for good or evil. "If the UK had decentralised test and trace, it would have worked a lot better than it did," says Patel.

Still, Patel thinks it's too late to look back. Even if we now started to enact door-to-door community tracing in the UK, there's no guarantee that it would make a difference to the current trajectory of the pandemic, he says. Switching the UK's system to one that copies another country could lead it to perform much worse than the status quo for several weeks while the new system is adopted, which could prove fatal in a delicate infection situation.

Instead, more fundamental problems need fixing. "If you can get people to comply with isolation orders, then your test and tracing system is also working quite well," says Patel.

\section{Commissioned, not peer reviewed}

Competing interests: I have read and understood BMJ policy on declaration of interests and have no relevant interests to declare.

1 Johns S. Effective test and trace could reduce R by up to $26 \%$. Imperial College London. 18 August 2021. www.imperial.ac.uk/news/202433/effective-test-trace-could-reduce-26.

2 Chung SC, Marlow S, Tobias N, etal. Lessons from countries implementing find, test, trace, isolation and support policies in the rapid response of the COVID-19 pandemic: a systematic review. BMJ Open 2021;11:e047832. doi: 10.1136/bmjopen-2020-047832 pmid: 34187854

3 Pavelka M, Van-Zandvoort K, Abbott S, etalCMMID COVID-19 working grouplnštitút Zdravotných Analýz. The impact of population-wide rapid antigen testing on SARS-CoV-2 prevalence in Slovakia. Science 2021;372:635-41. doi: 10.1126/science.abf9648 pmid: 33758017

4 WHO. Covid-19: virtual press conference. 30 March 2020. www. who.int/docs/defaultsource/coronaviruse/transcripts/who-audio-emergencies-coronavirus-press-conference-full30mar2020.pdf.
5 Coronavirus testing: statistics and research. Our World in Data. https://ourworldindata.org/coronavirus-testing.

6 Briggs A, Jenkins D, Fraser C, et al. NHS Test and Trace: the journey so far. Health Foundation. 23 September 2020. www.health.org.uk/publications/long-reads/nhs-test-and-trace-the-journeyso-far.

7 Lewis D. Why many countries failed at COVID contact-tracing-but some got it right. Nature 2020;588:384-7. doi: 10.1038/d41586-020-03518-4 pmid: 33318682

8 Homolka S, Paulowski L, Andres S, etal. Two pandemics, one challenge: leveraging molecular test capacity of tuberculosis laboratories for rapid covid-19 case-finding. Emerg Infect Dis 2020;26:2549-54. doi: 10.3201/eid2611.202602 pmid: 32956612

This article is made freely available for use in accordance with BMJ's website terms and conditions for the duration of the covid-19 pandemic or until otherwise determined by BMJ. You may use, download and print the article for any lawful, non-commercial purpose (including text and data mining) provided that all copyright notices and trade marks are retained. 